\title{
A hundred-year of Karl Jaspers' General Psychopathology (Allgemeine Psychopathologie) - 1913-2013: a pivotal book in the history of Psychiatry
}

Cem anos de Psicopatologia Geral (Allgemeine Psychopathologie) de Karl Jaspers 1913-2013: um livro decisivo na história da Psiquiatria

Antonio Egidio Nardi', Rafael Christophe Freire², Sergio Machado², Adriana Cardoso Silva ${ }^{3}$, José Alexandre Crippa ${ }^{4}$

\begin{abstract}
After a hundred-years of its publication, the Karl Jaspers' book, General Psychopathology, is still an indispensable book to psychiatrists and for all those who study psychopathology. It's a clear delineation of the phenomenological method for describing the symptoms of mental disorders that remains unmatched until nowadays. The book focuses on the relevance of phenomenological and hermeneutical methods in psychopathology. Although this work is grounded in the clinical thought and practices of the late nineteenth and early twentieth centuries, Jaspers' delineation of psychiatric methods in this work is still evaluated as unmatched to this day, a work that is indispensable to contemporary psychiatry. Jaspers also contributed with important articles and book reviews to psychiatric periodicals during the first two decades of the twentieth century.
\end{abstract}

Key words: psychopathology, philosophy, history, psychiatry.

\section{RESUMO}

Após cem anos de sua publicação, o livro de Karl Jaspers, Psicopatologia Geral, continua sendo uma obra indispensável para psiquiatras e para todos que se dedicam ao estudo de psicopatologia. Seu claro delineamento do método fenomenológico para a descrição dos sintomas dos transtornos mentais permanece intocável até hoje. O livro foca a relevância dos métodos fenomenológico e hermenêutico em psicopatologia. Apesar do trabalho ter sido baseado no pensamento e na prática clínica do final do século XIX e do início do século XX, a delineação dos métodos em psiquiatria de Jaspers é avaliado como ímpar até hoje, um trabalho indispensável para a psiquiatria atual. Jaspers também contribuiu com importantes artigos e revisões de livros para revistas psiquiátricas durante as primeiras duas décadas do século XX.

Palavras-Chave:psicopatologia, filosofia, história, psiquiatria.

After a hundred-year of its publication the Karl Jaspers' book, General Psychopathology ${ }^{1}$, is still an indispensable book to psychiatrists and for all those who study psychopathology. Its clear delineation of the phenomenological method for describing the symptoms of mental disorders remains unmatched until nowadays ${ }^{2}$. It was published in the most productive decade of the twentieth century. Just to cite four mark achievements in that period: 1) Sigmund
Freud published the Interpretation of Dreams (1900); 2) Eugen Bleuler introduced the primary signs and the term schizophrenia (1906); 3) Alois Alzheimer described the neurodegenerative disorder that bears his name (1907); and 4) Emil Kraepelin published the eighth edition of his textbook (1909). By 1911, Germany had many university psychiatric clinics, 187 public and 225 private asylums. They had almost 1,400 physicians specialized in psychiatry. This pool

\footnotetext{
${ }^{1}$ Professor Titular da Universidade Federal do Rio de Janeiro (UFRJ); Panic \& Respiration Laboratory, Institute of Psychiatry. UFRJ. INCT Translational Medicine/Conselho Nacional de Desenvolvimento Científico e Tecnológico (CNPq), Rio de Janeiro RJ, Brazil;

${ }^{2}$ Pós-doutorado na UFRJ; Panic \& Respiration Laboratory, Institute of Psychiatry. Federal University of Rio de Janeiro. INCT Translational Medicine/CNPq, Rio de Janeiro RJ, Brazil;

${ }^{3}$ Professora Adjunta da Universidade Federal Fluminense (UFF); Panic \& Respiration Laboratory, Institute of Psychiatry. UFRJ. INCT Translational Medicine/ CNPq, Rio de Janeiro RJ, Brazil;

${ }^{4}$ Professor Associado; Department of Neuroscience and Behavior, Faculdade de Medicina de Ribeirão Preto, Universidade de São Paulo (USP), INCT Translational Medicine/CNPq, São Paulo SP, Brazil.

Correspondence: Antonio E. Nardi; Laboratory of Panic \& Respiration, Institute of Psychiatry, Universidade Federal do Rio de Janeiro; Rua Visconde de Pirajá 407 / 702; 22410-003 Rio de Janeiro RJ - Brasil; E-mail: antonioenardi@gmail.com 
of research energy explains the primacy of Central Europe in the science of mind and brain in the second half of the $19^{\text {th }}$ century and the first half of the $20^{\text {th }}$ century ${ }^{3,4}$.

Karl Jaspers (1883-1969) was born in Oldenburg, Germany, studied law, qualified in Medicine in 1908 at Heidelberg. When Jaspers began his first unpaid employment, as a voluntary assistant in Heidelberg Clinic of Psychiatry, he did not confine himself to research in the natural sciences. He was already working within the terms of philosophy, even during his training at the clinic under Franz Nissl ${ }^{3}$. Jaspers turned to three prominent scientists to organize his work: the philosopher Edmund Husserl, the historian Wilhelm Dilthey, and the political scientist Max Weber. Jaspers took from Husserl an approach to examining patients. Husserl taught that the contents of the conscious mind of others could be accessed and described by the phenomenology. Jaspers defined a phenomenological approach to interviewing and examining psychiatric patients ${ }^{2,3}$.

Using the terminology from Dilthey, Jaspers distinguished two methods connecting life experience and the development of a mental disorder. "Explanation” (Erklären)

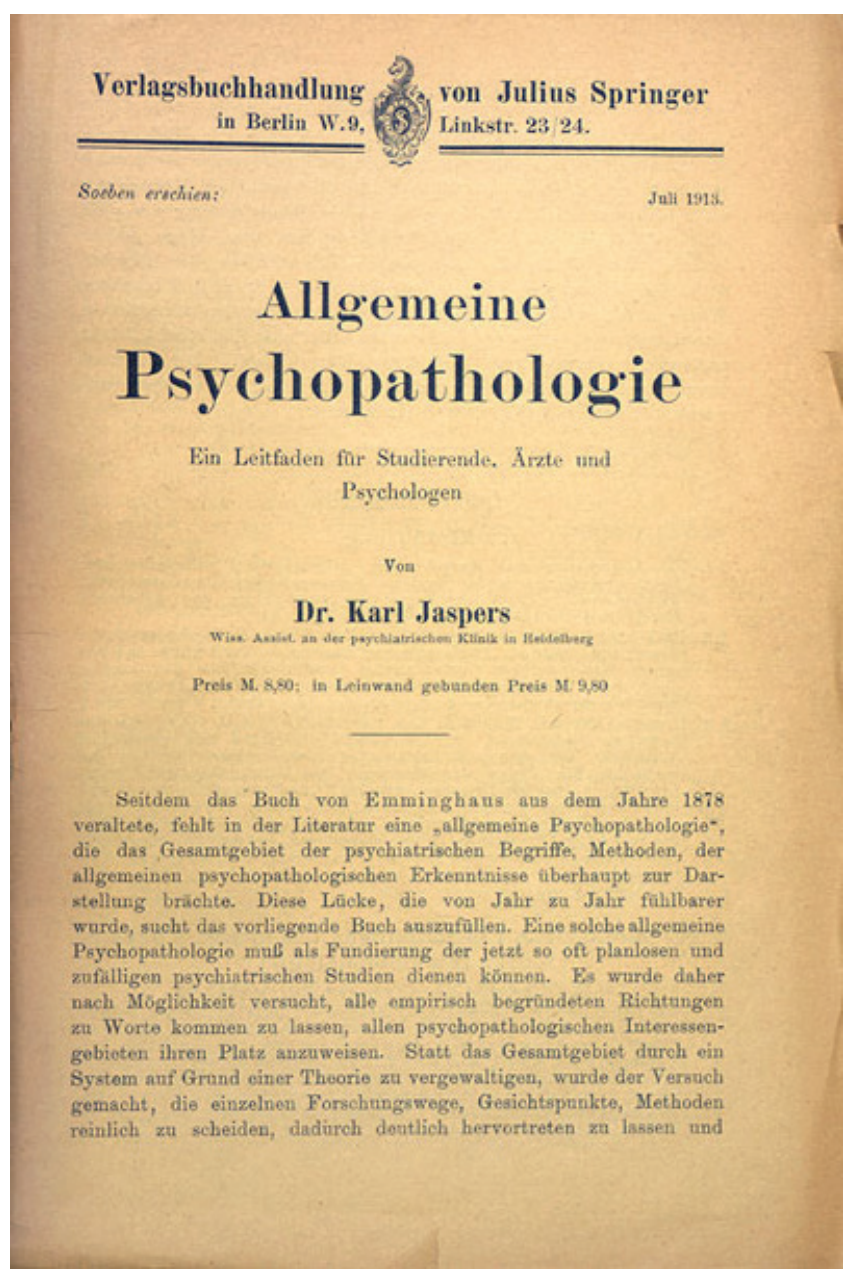

Figure. The first page of the first edition of Allgemeine Psychopathologie by Karl Jaspers, 1913. was the attempt to discern nature's law acting impersonally, through causal connections; and "understanding" (Verstehen) an attempt to demonstrate that a mental disorder could emerged from a conflict between experience and its emotional consequences ${ }^{2,3}$. The understanding could be empathically appreciated for the person even though not statistically demonstrable. Jaspers made an important distinction between that which in meaningful and allows empathy, and that which is ultimately un-understandable the essence of the psychotic experience. One can empathize with the content of a patient delusion but one cannot understand or see a meaningful connection in the occurrence of the delusion itself $f^{1}$. The delusion is always incomprehensible and unreal. It is possible to understand from a knowledge of the patient's background the reason for his content, but it is not possible to understand why the patient believe in something that is demonstrably false $\mathrm{e}^{1,3}$.

Psychiatry learned from Jaspers that there is something available beyond Freud and Kraepelin, i.e., there is something beyond the naïve conflict between natural science and the psychology of classical psychoanalysis ${ }^{4,5}$. What is needed is a total new conception of what psychiatry is all about, and this "new" conception was actually laid out for the field by Jaspers almost a century ago ${ }^{5}$. Jaspers' legacy for contemporary psychiatry lay in his clarification of scientific method in psychiatry, including the distinction between the method of "understanding" (Verstehen) and the method of "causal explanation" (Erklären). Jaspers also discusses the different meaning that can be given to the terms primary and secondary when applied to symptoms. The distinction may be in terms of understanding, in that what is primary can be reduced no further by understanding; or the distinction between them may be one of causality, where primary is the cause and secondary the effect $^{3,5}$. Most of the problems that Jaspers noted in 1913 remain as problems to psychiatry today ${ }^{2,4}$.

In 1911 Jaspers was asked by Karl Wilmanns to undertake a general textbook of psychopathology ${ }^{3}$. Published in 1913, year which Jaspers received his habilitation in Psychology, General Psychopathology ${ }^{1}$ would become the single most influential text in psychopathology (Figure shows the first page of this edition). The book went through a number of editions, Jaspers completing the ultimate version in 1942 with the help of Kurt Schneider but it was only published in 1946. The most recent reprint of this version came out in 1973 as the "ninth edition”. The English translation was greatly delayed, and only in 1962 Jan Hoenig and Marian Hamilton bring out the seventh edition. It remains a classic guide and the foremost book to the study of psychopathology ${ }^{3,4}$.

The book consists of two volumes and six parts. The Introduction and Appendix both function as largely general reviews of the major topics discussed in the text, particularly the understanding/causal explanation distinction, and the importance of conscious methodological awareness ${ }^{1,5}$. The 
first part is a section on phenomenology, where Jaspers carefully describes various psychopathological states. The second part consists of a discussion of those phenomena using the method of understanding (Verstehen), and the third part does the same using the method of causal explanation (Erklären). These being the two ways of knowing that Jaspers introduces into psychiatry, the fourth part ("Conception of the Psyche as a Whole") seeks to connect the two, and does so in discussions of nosology and personality. The fifth part deals with social and historical factors affecting psychiatry. And the sixth and last part ("The Human Being as a Whole") discusses the connection between philosophy and psychiatry in more detail and introduces some Jaspers' philosophical ideas.
This last step makes sequential sense of Jaspers since he sees his entry to philosophy as occasioned by recognizing the limits of what he could know through science (specifically psychopathology) ${ }^{5}$.

The book focuses on the relevance of phenomenological and hermeneutical methods in psychopathology ${ }^{1}$. Although this work is grounded in the clinical thought and practices of the late nineteenth and early twentieth centuries, Jaspers' delineation of psychiatric methods in this work is still evaluated as unmatched to this day, a work that is indispensable to contemporary psychiatry ${ }^{5}$. Jaspers also contributed important articles and book reviews to psychiatric periodicals during the first two decades of the twentieth century.

\section{References}

1. Jaspers K. General Psychopathology. Baltimore: The John Hopkins University Press, 1997.

2. McHugh PR. Foreword to the 1997 edition. Genius in a Time, Place, and Person. In: Jaspers K. General Psychopathology. Baltimore: The John Hopkins University Press, 1997.
3.

Kirkbright S. Karl Jaspers: a biography. Navigations in truth. New Haven: Yale University press, 2004.

4. Shorter E. A historical dictionary of psychiatry. New York: Oxford University Press, 2005.

5. Salamun K, Walters GJ. Karl Jaspers's Philosophy. Expositions \& Interpretations. New York: Humanity Books, 2008. 